\title{
Analysis of Poaching Activities in Kainji Lake National Park of Nigeria
}

\author{
Henry M. Ijeomah ${ }^{1}$, Augustine U. Ogogo ${ }^{2} \&$ Daminola Ogbara ${ }^{1}$ \\ ${ }^{1}$ Department of Forestry and Wildlife Management, University of Port Harcourt, Nigeria \\ ${ }^{2}$ Department of Forestry and Wildlife Resources Management, University of Calabar, Nigeria \\ Correspondence: Henry M. Ijeomah, Department of Forestry and Wildlife Management, University of Port \\ Harcourt, Nigeria. Tel: 234-806-034-4776. E-mail: henryijeomah@yahoo.com
}

Received: November 2, 2012 Accepted: December 5, 2012 Online Published: December 15, 2012

doi:10.5539/enrr.v3n1p51

URL: http://dx.doi.org/10.5539/enrr.v3n1p51

\begin{abstract}
Analysis of poaching activities in Kanji Lake National Park (KLNP) of Nigeria was conducted with the aim of investigating the forms and trend of encroachment experienced in the premier protected area, and to determine the locations where poaching occur. Data for the study were collected using two sets of structured questionnaires and secondary data obtained from administrative records. A set of structured questionnaires was administered randomly to $30 \%$ of households in ten selected communities close to the park. The second set of questionnaires was administered to $30 \%$ of the staff in park protection section of KLNP. In all 403 households and 53 staff members were sampled. Data on poaching arrest were obtained from administrative records. Data collected were analysed using descriptive statistics in form of frequencies of count, percentages, graphs, bar chart and pie chart. Grazing of livestock and hunting were the form of encroachment most arrested in the park between 2001 and 2009. Poachers were most attracted in the park by Animals (92.06\%), fuel wood (82.13\%), Herbs $(73.95 \%)$, and Fish (73.95\%). Between 1995 and 2009 KLNP recorded the highest arrest (372) of poachers in 1999. Increase in the number of staff of KLNP had no significant effect in the number of poachers arrested within this period. Oli and Ibbi were respectively ranked first $(69.98 \%)$ and second $(45.91 \%)$ by household respondents as major areas of poaching. About $52.11 \%$ of households are optimistic that poaching can be stopped while $39.5 \%$ perceived that it can only be minimized. However, $39.15 \%$ of household respondents suggested creation of employment opportunities for households as a strategy that can stop poaching in KLNP.
\end{abstract}

Keywords: encroachment, Kainji Lake National Park, wildlife exploitation, Nigeria

\section{Introduction}

Wildlife is facing serious challenges world over, and many fauna and flora species are continuously driven closer to extinction on daily basis. Less than nine percent of the earth has been set aside for protected areas and there is constant pressure from rampant development and commercial activities to further reduce these areas (Anonymous, Undated). Increased human and cattle population in most countries is continuously putting more pressure on forest resources and has ultimately caused fragmentation and degradation of wildlife habitats. This, along with increases in wildlife population in Protected Areas has resulted in wildlife spilling over to non protected areas. The effects of all these pressures culminate in increased man and animal conflicts; leading to revenge killings and poaching (National Tiger Conservation Authority, Undated). However, many modern poachings are majorly embarked upon as business ventures especially as man has discovered the potentials of harnessing wildlife resources for economic empowerment.

Poaching and illegal trade in wildlife has become an organized, lucrative and a capital intensive business, with trafficking routes extending from remote national parks and reserves, where animals are trapped and killed, to major urban centres where they are sold and consumed (Goodall, 2011). It is estimated that trade in wildlife products is just next to narcotics, valued at nearly 20 billion dollars in the global market, of this more than one third is illegal (National Tiger Conservation Authority, Undated).

Due to this high commercial value of wildlife products, tension in protected areas is continuously increasing at a global scale. Poaching, therefore, has become more universal and a frequently occurring phenomenon. From the depths of the oceans to the highest mountaintops, no environment is spared from poaching and all wildlife 
species can be drawn into the vast illegal trade (Granby Zoo, 2012).

Nearly every country faces modern poaching issues though different items, species or wildlife products are poached. In North America poachers kill large numbers of wild animals as well as various species of fish, and even the ginseng plant. In Africa, as well as other continents, animals being killed are solely for body parts. The African Elephant (Loxodonta africana) and Rhinoceroses are more recent victims of poaching. Poachers, most times, cut the elephant's face off, and leave the body of the species to rot in the forest. For instance, Guardian (2012) reported that heavily armed poachers from Chad and Sudan decimated more than 200 individuals of elephants in six weeks in Bouba Ndjida national park of Cameroon in a "massacre" fuelled by Asian demand for Ivory.

In Krudger National park of South Africa, Rhinoceroses (Ceratotherium simum and Diceros bicornis) are the major target for poaching. Their horns that are so valuable made Rhinos the target for groups of poachers in Africa who sell the horns to the Far East users at high prices. These organized poachers often hire helicopters and use high - tech equipment such as night - vision goggles and sedative drugs. Before mid 1980s, due to Ivory poaching, the number of elephant and Rhino in the Serengeti National Park of Tanzania, and other protected areas in Tanzania seriously declined. Ivory poaching decimated the elephant population in Serengeti National Park until only a few hundred were left in the park, and the thriving rhino population dwindled to just two individuals (Serengeti, 2000). But the 1989 worldwide Ivory Ban further eased the burden on the park's elephant population. Nevertheless, meat poaching continued. In an average year, local people living around Serengeti National Park illegally kill about 40,000 animals, including Wildebeest (Connochaetes gnu), Zebra (Equus quagga), Giraffe (Girraffa camelopardarlis), Buffalo (Syncerus caffer), Impala (Aepyceros melmpus) and many other species that are caught in poachers' snares or pit fall traps (Serengeti, 2000).

The wildlife products poached and traded illegally from India are Musk Deer (Moschus moschiferus) for cosmetics; Bear (Selenarctos thibetanus) for skin and bear bile; Elephant (Loxodonta africana) Tusk for ivory; Rhinoceros horns for aphrodisiac; Tiger (Panthera tigris) and Leopard (Panthera pardus ) skins for fashion products, oriental medicines and food; Snakes and Monitor Lizard (Veranus niloticus) skins for leather industry; Birds for pet trade and feather for decoration; Swiftlet (Aerodramus unicolor) nests for soups; Mongoose (Herpestes edwardsii) for bristles; Turtles for meat and soup; and Tibetan Antelope (Pantholops hodgsonii) for shawls (National Tiger Conservation Authority, Undated). In Great Smoky Mountain National Park, ginseng is the attraction to poachers while for Petrified Forest National Park, fossilized trees are stolen. In Redwood National and State Parks' of California's North Coast, poachers cut down and steal redwood trees (Finegan, 2008).

Theft of Saguaro cacti (Carnegiea gigantea) a slow-growing plant has been a major problem for decades in Saguaro National Park. Years of population growth and development of new subdivisions in the West have increased demand for native landscaping. Saguaro is difficult to propagate, and poachers typically target plants that are about forty years old, and five to seven feet in height. Cacti of that size are easy to transport, and a single saguaro can fetch hundreds of dollars when sold to nurseries or landscapers. An estimate of 250,000 desert plants were illegally dug and sold in Arizona alone in 1979, and pressures on desert ecosystems have continued to mount (Burnett, 2009).

Sariska Tiger Reserve in India has become devoid of Tigers due to poaching. In Shenandoah National Park, the ginseng (Panax spp.) and the Black bears (Ursus americanus) that thrive along the edge of the Blue Ridge Mountains are the biggest attraction to poachers. The price of wild ginseng on the open market ( $\$ 400$ a pound) is ten times higher than the price of cultivated ginseng. And a Black bear's dried gallbladder sells for $\$ 1,000$ in Asia, making it worth more per ounce than cocaine (Eilperin, 2005).

Living things are not the only targets by poachers. Potsherds (archeological artifacts) from national parks are poached and sold. In some cases, poachers transport their poached goods by water to evade authorities. This happens in California's Redwood National Park where poached Red woods (ancient trees) are floated downstream. Park visitors also have taken more obscure items with less commercial value, such as owl pellets, the fur-coated bones that owls regurgitate after eating small prey (Eilperin, 2005).

The poaching of sea turtle eggs from their buried nests is one of the worst threats that these species face in many beaches. Poaching reduced the population of leatherbacks in Malaysia from 2,000 nesting females to 20 in only a generation. While poaching of eggs is illegal, poor enforcement and economic conditions allow this destructive activity to occur. Poaching on any Central American beach (and perhaps the world) is close to $100 \%$ if not protected. Studies have estimated various levels of poaching at different Costa Rica beaches, including 95\% in the Guanacaste region, 98\% in Esterillos, Costa Rica, and a 100\% poaching rate in Punta Banco in 1995. In other 
countries, such as Honduras, where there is some record, it indicates poaching at similar levels (Sea Turtle Restoration Project, Undated). In the case of Barangay Handumon in island of Jandayan, Getafe the item targeted is entirely different there poaching of fish with dynamite is always experienced.

With these recently increased poaching pressure experienced in many protected areas across the globe, it becomes imperative to have an in depth study of the forms and trend of encroachment in the premier national park of Nigeria, Kainji Lake National park due to its location - close to the Niger Republic. The study therefore investigates the forms of encroachment experienced in KLNP and analyses the trend of encroachment in the park.

\section{Methodology}

\subsection{Study Area}

The study area Kainji Lake National Park (KLNP) is geographically located at Latitude $9^{\circ} 50^{\prime} 19^{\prime \prime}$ N, Longitude $4^{\circ} 34^{\prime} 24^{\prime \prime}$ E. The park was established in 1979 by the amalgamation of Borgu game reserve (in Niger and Kwara States) and Zurguma game reserve (in Niger State), which were two former game reserves. Before the merger, these the two sectors had been gazetted in 1962 and 1971 respectively as game reserves by the then Northern Regional Government.

The study area (KLNP) which is a savanna climate has a total area of 5,340.82 sq km and is located in the North West central part of Nigeria between Niger and Kwara States. The area has two distinctive sectors known as the Borgu and Zurguma sectors (Marguba, 2002) as shown in Figure 1.

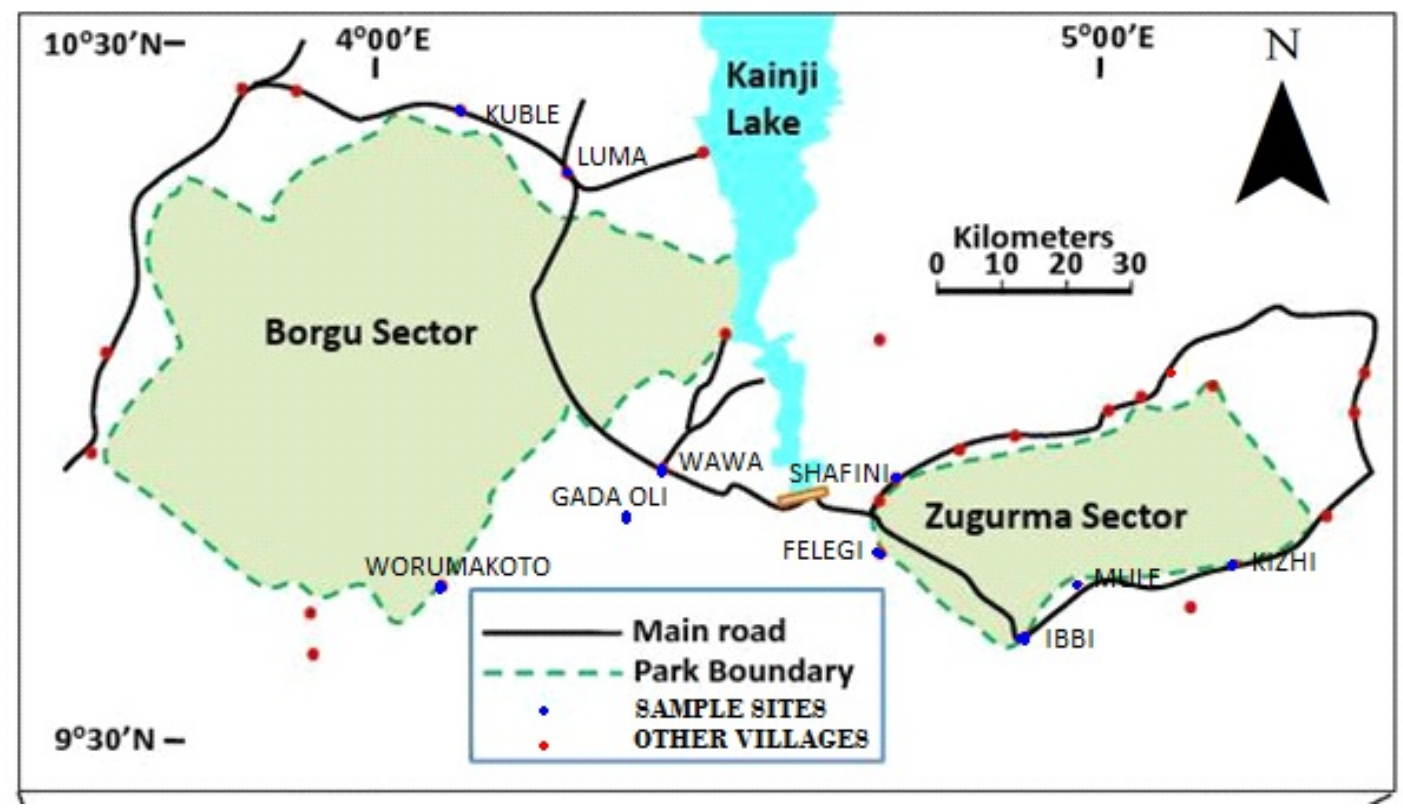

Figure 1. Map of Kainji Lake National Park

\subsubsection{Method of Data Collection}

Two sets of structured questionnaire, and secondary data obtained from administrative records (information unit) of the Kainji Lake National Park served as instruments for data collection. A set of structured questionnaire was administered randomly to households in selected communities bordering the park. The second set of questionnaire was administered to thirty percent of staff in park protection section of KLNP. In all, 403 households and 53 staff members were sampled.

\subsubsection{Statistical Design}

Based on closeness to the park, ten communities (five from each sector) were selected from communities bordering the park. Listing of households was conducted in selected communities using people who are quite conversant with these communities. Thirty percent of households in the selected communities were sampled as presented in Table 1a. 
Table1a. Proportional allocation of questionnaire to households in selected communities

\begin{tabular}{lll}
\hline Communities & Estimated Population & Thirty percent of population (\%) \\
\hline Ibbi & 477 & 159 \\
Feligi & 30 & 10 \\
Mulea & 30 & 10 \\
Shafini & 30 & 10 \\
Kizhi & 20 & 7 \\
Wawa & 477 & 159 \\
Gada-oli & 60 & 20 \\
Kuble & 15 & 5 \\
Luma & 50 & 16 \\
Worumakoto & 20 & 7 \\
Total & $\mathbf{1 2 0 9}$ & $\mathbf{4 0 3}$ \\
\hline
\end{tabular}

\subsection{Method of Data Analysis}

Descriptive statistics in form of frequencies, percentages, pie chart, and bar chart were used for data analysis.

\section{Results}

\subsection{Forms of Poaching in KLNP}

Results on forms of poaching are presented in Figure 1 while table $1 \mathrm{~b}$ shows resources that attract poachers to KLNP.

\section{Poaching activities}

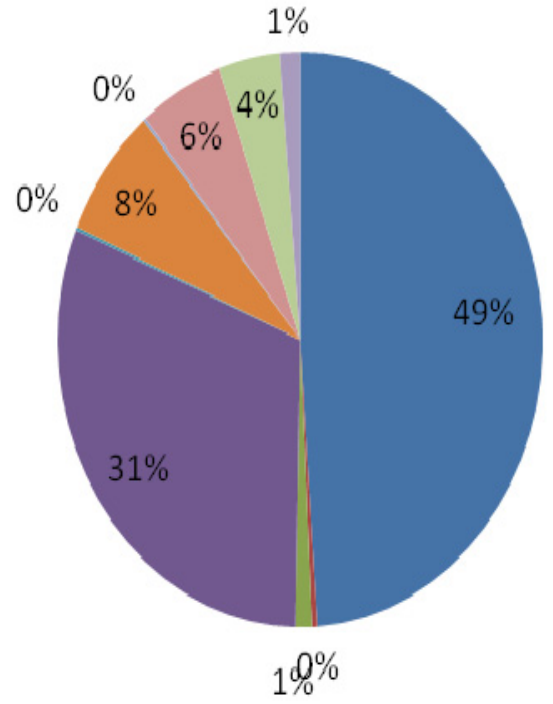

Grazing of livestock

- Illegal entry

Minning

- Hunting

- Conspiracy

Fishing

Fuelwood/Charcoal

Farming

Lumbring

Figure 1. Percentages of different poaching activities between 2001 and 2009

Source: Field Survey, 2011. 
Table $1 b$. Resources that attract poachers to encroach into the park

\begin{tabular}{lll}
\hline Resources collected from the park & Frequency & Percentage \% \\
\hline Animal & 371 & 92.06 \\
Honey & 133 & 33.00 \\
Fuel wood & 331 & 82.13 \\
Herbs & 298 & 73.95 \\
Fish & 298 & 73.95 \\
wood for timber & 85 & 21.09 \\
Water & 52 & 12.90 \\
Seeds & 101 & 25.06 \\
Seedlings & 24 & 5.96 \\
Palm wine & 123 & 30.52 \\
Spices & 250 & 62.03 \\
Birds & 238 & 59.06 \\
Soil & 69 & 17.12 \\
\hline
\end{tabular}

Source: Field Survey, 2011.

\subsection{Trend of Arrests in KLNP}

Results on trend of poaching were assessed using trend of arrest as an indicator (Figures 2 and 3).

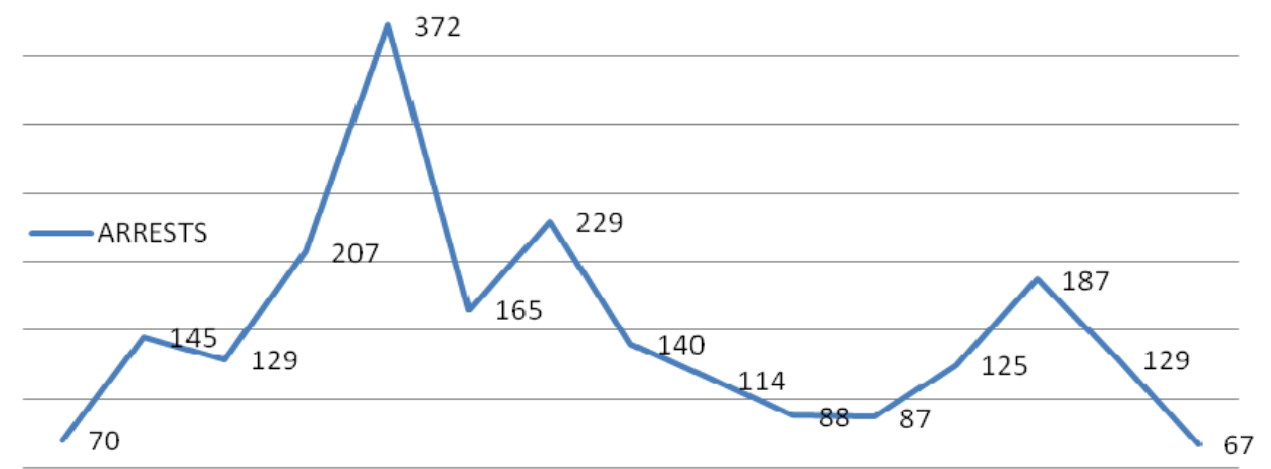

199519961997199819992000200120022003200420052006200720082009

Figure 2. Trend of poaching arrests between 1995 and 2009

Source: Field survey, 2011. 


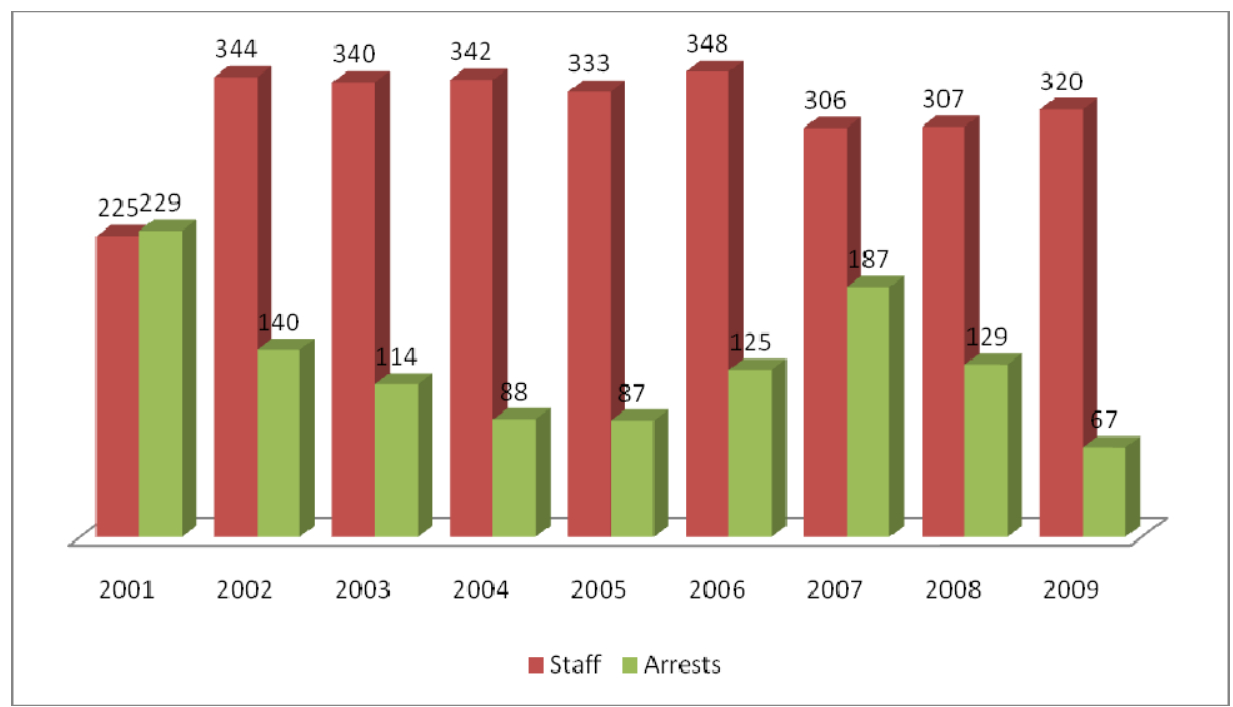

Figure 3. Relationship between number of arrested poachers and staff strength

Source: Field Survey, 2011.

\section{Household Awareness of Location of Park resources}

Respondents' awareness of locations of park resources is through experience from elders (31.02\%) and personal findings (22.08\%) (Table 2).

Table 2. Households source of information concerning locations of park resources and reasons for collecting them

\begin{tabular}{llll}
\hline Parameters & Variables & Frequency & Percentage \\
\hline Sources of information & Personal findings & 89 & 22.08 \\
& Experience from elders & 125 & 31.02 \\
& No response & 189 & 46.90 \\
Reasons for collecting these resources & Generate income & 310 & 76.92 \\
& Usage & 181 & 44.91 \\
\hline
\end{tabular}

Source: Field Survey, 2011.

Respondents Awareness of Areas Poaching Takes Place

Most respondents (69.98\%) mentioned Oli as the range where encroachment is most experienced (Table 3).

Table 3. Areas of poaching in KLNP as identified by household respondents

\begin{tabular}{llll}
\hline Locations & Frequency & Percentage & Rank \\
\hline Oli & 282 & 69.98 & 1 \\
Ibbi & 185 & 45.91 & 2 \\
Kigera & 105 & 26.05 & 3 \\
Kaiama & 77 & 19.11 & 4 \\
Kulho & 73 & 18.11 & 5 \\
Doro & 52 & 12.90 & 6 \\
Kuble & 52 & 12.90 & 6 \\
Wurumakoto & 56 & 13.90 & 7 \\
Kemenji & 24 & 5.96 & 8 \\
\hline
\end{tabular}




\subsection{Strategies to Stop Encroachment}

Table 4 shows that many of the household respondents $(52.11 \%)$ believed that poaching can be stopped especially through employment (35.5\%), provision of money for households adjoining the park $(35.5 \%)$ and creation of Awareness (23.43\%).

Table 4. Household respondents' suggestions on strategies to stop poaching

\begin{tabular}{llll}
\hline Parameter & Variables & Frequency & Percentage \\
\hline If poaching can be stopped? & Yes & 210 & 52.11 \\
& No & 161 & 39.95 \\
& No response & 32 & 7.94 \\
Strategies & Employment & 129 & 35.15 \\
& More buffer zones & 36 & 9.81 \\
& Awareness & 86 & 23.43 \\
& Workshop/seminar & 16 & 4.36 \\
& Provision of Mgt. demands & 28 & 7.63 \\
& Basic amenities & 44 & 11.99 \\
& Skill acquisition & 20 & 5.45 \\
& Park patrol & 4 & 1.09 \\
& Provision of money to households & 4 & 35.15 \\
\hline
\end{tabular}

Source: Field Survey, 2011.

\section{Discussion}

\subsection{Forms of Encroachment in KLNP}

Forms of poaching such as grazing, hunting, farming and fishing are high when compared with illegal entry which could be for roaming, relaxation, site seeing and other reasons not connected with income generation (Figure 1). This can be attributed to the fact that wildlife resources are vital means of survival for households adjoining the park. Analysis of forms of poaching for a period of nine years (Figure 1) using arrest as an indicator revealed that grazing has the highest occurrence followed by hunting while fuel wood/charcoal gathering and conspiracy had the lowest. In reality, poaching of game animals occurs most in the park. Though encroachment in the form of grazing is equally very high and the impact is quite much but the result from the arrest record (Figure 2) cannot be unconnected with the fact that apprehension of persons involved in poaching activity such as grazing is the simplest (rangers, personal communication). This is due to the fact that the act of grazing leaves anti poaching patrol team a "lead or trace" that enables them to apprehend poachers. Examples of these 'leads' always observed are foot prints of their herds as well as deformation of pastures.

It is easier to observe these leads or indicators than the ones indicating encroachment by hunting. A hunter may successfully hide in the bush on detecting the presence of anti poaching patrol whereas if herdsmen hide, their herds would be seen and seized. Interactions with park officials have revealed that sometimes the herdsmen use charms to hide without being easily seen by antipoaching patrol teams. However, their herds are arrested. After waiting for a while, they report to claim their herds and will be arrested. This increases the record of poachers arrested for grazing. In the case of hunting, the poachers can use charms "African technology" to confuse the rangers and escape without leaving anything behind to trace them or bring them back. Hunting is more prevalent but encroachments in form of grazing are most arrested. Over the nine years of study, record of poaching arrest revealed that almost half ( $49 \%$ ) of the culprits encroached into the park for grazing of cattle (Figure 1). Hunting is high because communities living around the protected area poach to supplement their starch based diet with protein. This is similar to Kepe, Cousins and Turner (2000) in Mkambati Nature Reserve in South Africa.

Encroachment for grazing and that of charcoal or fuel wood gathering differs greatly (Figure 1) because alternative cooking fuel such as kerosene can be provided and used in place of charcoal/fuelwood unlike grazing that can hardly be substituted. Cattle rearers, can hardly find other suitable, readily available and culturally 
acceptable free resource to serve as a substitute for vegetation. Moving herds from one location to another requires food and water and as such cannot be easily controlled. In a situation where herds are to be moved from one point to another it becomes difficult to stop them from grazing since they require food and water to live. This also creates an avenue for Fulani cattle rearers to hunt or kill animals that pose threats to their herds. This also agrees with the findings by the Nigerian Environmental Study/Action Team (NEST) (1991). However, on basis of preference, households prefer cooking with wood or charcoal because of their large size. This can be related to the reason why majority $(82.5 \%)$ of the respondents indicated that poachers collect fuelwood from the park (Table 1).

\subsection{Trend of Poaching in KLNPS}

Analysis of records of arrests between 1995 and 2009 shows no specific or uniform pattern of flow in arrests of poachers. The trend of poaching for the 12 years is inconsistent with increases and decreases until 2007 when it decreased consistently till 2009 (Figure 2). Similar trends of poaching of Tiger and Leopard were recorded by the Tiger Project Conservation Authority (Undated) between 1998 and 2003. The KLNP recorded the highest arrests in 1999 with 372 arrests.

In 1995 only 70 poachers were arrested. The number of culprits arrested increased to 145 in 1996 but decreased to 129 in 1997 and increased tremendously to 207 in 1998. This tremendous increase in the number of arrests can be attributed to a more effective management in the park. The park was divided into eight ranges for effective patrol and was adequately equipped with various anti poaching devices including seven new double barrel shot guns and 1000 rounds of cartridge. Besides, the two sectors of the park were graded, renovated and furnished to accommodate rangers. Also, A. P. Leventis donated a parachute to further improve anti poaching activities. The effects of the antipoaching device reflected in 1999 when 372 poachers were arrested. Besides, the rangers may have decided to be more serious with their work in other to impress the donor of the anti poaching facilities. The number of arrests however decreased to 165 in 2000 . The decrease could be attributed to the fact that the poachers felt that the antipoaching patrols had become more armed, therefore withdrew, to look for new strategies that could enable them overcome the patrol team of the park. With time, poachers resort to the use of arms and charms to confuse rangers inside the park. Poachers can go to the extent of using charms to attract animals. Some charms confiscated from arrested poachers are kept in the museum of Kainji Lake National Park as evidence (Personal Observation). This is similar to the report of Ijeomah and Aiyeloja (2010) in Ijebu Ode of Ogun State, Nigeria where hunters use charms to attract or remote control animals to their traps. The rangers also resorted to use charms "African technology" to detect the direction of poachers' movement in the park.

The increase in arrests to 229 in 2001 cannot be unconnected with the fact that new strategies by the poachers to escape arrest were still detected and overpowered by the patrol teams. Consequent upon the effective antipoaching patrol by the rangers, arrest decreased progressively to 140,114, 88 and 87 in 2002, 2003, 2004 and 2005 respectively. The consistent reduction in arrest can also be related to the fact that the poachers were escaping arrest either because the rangers were no longer as effective as before or that the rangers' antipoaching devices had become ineffective due to poor maintenance. Though, it could also imply that poaching has become reduced in the park.

However, reduction in the number of poachers arrested cannot be used as the only indicator to rate poaching in the park because if not for the improvement on antipoaching facilities in 1998 that led to the arrest of 207 (78 poachers more than the record of 1997) the management would not have known that such large number of poachers have been encroaching into the park without being caught. Reduction in poaching arrest could also be caused by inefficiency of the anti-poaching patrol team due to lack of motivation by the management of KLNP.

This increase in 1998 was due to motivation of the patrol team by the management coupled with efforts to overcome all poaching strategies by the poachers. The number of arrest also decreased to 126 in 2008 . The fact that the year 1999 recorded the highest number of arrest indicates that if the anti-poaching patrol teams were well equipped and motivated, poaching can be reduced to a bearable minimum in protected areas in Nigeria. Figure 3 showing comparison between staff strength and number of poachers arrest revealed that in 2001 staff strength was 255 while that of 2002 was 344 - an increment of about 89 staff, yet the number of arrested poachers in 2001 was 229 while 2002 that had more staff arrested only 140. A similar trend also occurred in 2006 and 2007. This implies that some of the staff were not efficient or that some of the employed staff were not fit for the job. It can also be attributed to the fact that poaching decreased during those periods.

\subsection{Sources of Information on Where to Locate the Animals and Reasons for Poaching}

Based on personal findings and experience (Table 2) respondents are aware of locations of resources in the park as entering of the parkland to harness forest resources was not a crime before the park was gazzetted. Thus, 
households are aware of where to locate the animals and other resources, as the parkland had been their hunting ground and a source of vital resources for their survival. They have good understanding of the access and feeder roads inside the park (Table 2).

Respondents' knowledge of where to locate park resources can also be related to the fact that they had at one time or the other embarked on poaching of park resources for income generation or usage (Table 2) or have relations who had been entering the park to poach.

\subsection{Respondents' Ranking of Poaching Activities in Ranges of KLNP}

Results in Table 3 shows that most respondents ranked Oli first in the order of poaching in the park. Out of the eight ranges, Oli has more animals because the Niger River has some channels through which it flows into the forest therein. Hence, the animals can easily access water to drink unlike in Ibbi and Kali ranges or Kaiama post (boundary between Kwara State and Niger State). Oli camp is the most popular place in the park. It is very popular as the major camp where tourists go to view animals. This agrees with Ogunjinmi and Ijeomah (2010). In Oli while inside the chalet one can site animals roaming about. Besides, animals feel more secured in Oli and can therefore go close to people in many cases unharmed. Though the presence of these animals can attract poachers but it is relatively more difficult to poach in Oli camp. Poachers are more afraid to poach in Oli as they know that the patrol there is intense. Nevertheless poaching still take place as the presence of many games is a great temptation to poachers, especially those who are ready to take risks. In 1999 and 2000, 75 and 11 poachers were respectively arrested in Oli camp. The 75 arrests in the year 1999 were the highest among all the ranges.

In Ibbi the animals hide probably because of poachers. Siting of animals is relatively more difficult from Ibbi unlike Oli. Ibbi is closer to the town than Oli camp. It is surrounded by villages to the town and it is therefore easier to poach in Ibbi than in Oli. This could be attributed to the reason it was ranked second in the order of poaching activities (Table 3). In 1999, 2000, 2007 and 2008, the numbers of poachers arrested in Ibbi were 50, 29,11 and 11 respectively.

Kuble has a broken culvert that hinders accessibility to the area, thus hinders patrol by rangers. Because of the relatively far distance, rangers can hardly cover the distances on foot. The patrol Hilux stops at the broken culvert and rangers trek on foot to the forest, where they remain till the agreed day for the Hilux to return and carry them. They could even stay for two or more days inside the forest. Even if they arrest poachers, the culprit will stay with them in the forest till the scheduled day and time for the patrol Hilux to return to carry them at a pre scheduled location.

Another route to access Kuble, apart from being narrow is marshy and can hardly support movement of vehicles. For the far distance of Kuble even if animals are caught, taking them home becomes a very big challenge for poachers. However, 23, 29, 25 and 16 arrests of poachers were made therein in 1999, 2000, 2007 and 2008.

Kali range is also far from Oli or Roan Gate but there is accommodation for the rangers there. The major resources poached in Kali range are fishes. As dry season approaches, while the water level in River Oli reduces gradually and consistently based on distances (kilometer) away from River Oli and close to Kali range, most aquatic lives in the water body correspondingly migrates from Kilometre 3 through 5,8 and 15 before getting to Kali range. No matter the degree of dryness, Kali is least affected and therefore has much fish in the part of Oli river that flows to the range.

Wurumakoto and other ranges are far from Oli camp. Less poaching activities take place therein as the animals tend to move closer to where they are more secure. The park management has fewer members of staff there. Even park workers dislike being posted to those places due to their far distances from Oli. It is possible that poaching may be taking place there at a lower level without the poachers being caught.

Wurumakoto is not easily accessible as it is far coupled with the fact that the roads leading to the range is bad. For one to access Wurumakoto, the poacher needs to pass through about three other ranges. And it is difficult and more risky for poachers to operate that way successfully without being seen. Record of arrest from Kainji Park Management revealed that no poacher was arrested in Wurumakoto in 1999, 2000, and 2008. However, 5 arrests were made in 2007, and that was the least in all the ranges in that year.

Different items are poached from the other ranges. In Oli, animals are mostly poached followed by fish. The major form of encroachment in Ibbi is grazing. This can be attributed to the fact that the range is close to the villagers who are mostly cattle rearers. Some of the grazers together with other villagers encroach to get herbs which they put inside bottles and sell to generate income. In Kuble, the major form of encroachment is hunting. Similarly, different items are poached from different sections of Pandam game reserve in Plateau State, Nigeria. The major reasons for encroaching into different sections of Pandam game reserve are hunting, fishing, 
collection of fuel wood and tapping of palm wine (Ijeomah, 2007).

\subsection{Respondent's Suggestions on How to Check Poaching}

Some respondents stated that poaching cannot be stopped (Table 4). This can be attributed to the high level of poaching they noticed around the park irrespective of series of anti poaching campaigns in the communities bordering the park. It can also be ascribed to the prevailing perception or mindsets of community members concerning poaching. Some members of the studied communities have emphasized that they would never stop poaching since it was inherited from their parents. As their parents did not stop it, they must continue with it. An arrested poacher, who had earlier been caught twice, while in police custody still emphasized that he would continue poaching (Per. Com.). Even if arrested poachers are being penalized, they hardly show any sign of remorse, when arrested, and their relations always believe that they would still be released.

Many respondents however believe that poaching could be stopped if the demands of host communities are provided by the management of the park. The fact that provision of employment tops the list of suggested strategies to check poaching reveals the high level of dependency on the park. It is also a reflection of the continuously increasing rate of unemployment in Nigeria.

\section{Conclusion}

Kainji Lake National Park is not fully protected against poaching activities. Forms of anti poaching support given to the management of KLNP by host communities are pretentious and done out of fear of not attracting the wrath of the federal government of Nigeria, which could lead to the removal of community leaders. If the security situation of the park is not improved, most of the resources of the premier National Park of Nigeria will vanish from existence. The rangers should be encouraged to be more committed with anti poaching activities through provision of attractive risk allowances and monitoring.

\section{References}

Anonymous (Undated). wildlife 1.org

Burnett, J. (2009). Cactus poachers at Saguaro National Park receive stiff sentences, National Park Travellers. Retrieved from http://www.nationalparkstraveler.com/2009/11/cactus-poachers-saguaro-national-park-receive-stiff-sentence s4986

Eilperin, J. (2005). Poachers Looting National Parks of Treasures, The Washington Post. Retrieved from http://www.washingtonpost.com/wp-dyn/content/article/2005/10/23/AR2005102300796.html

Finegan, C. (2008). Poaching Trees from Red wood National Park, National Park Travellers. Retrieved from http://www.nationalparkstraveler.com/2008/03/poaching

Ganby Zoo. (2012). To the rescue of endangered species. Retrieved from http://www.especesmenacees.ca/en/excessive-trade.php

Goodall, J. (2011). Retrieved from www.janegoodall.org

Guardian. (2012). Poachers slaughter 200 elephants in Cameroon national park in six weeks. Retrieved from http://www.guardian.co.uk/environment/2012/feb/17/poachers-slaughter-200-elephants-cameroon.

How Stuff Works Inc. (2012). Modern poaching, How Stuff Works, Incorporation. Retrieved from http://adventure.howstuffworks.com/outdoor-activities/hunting/traditional-methods/poaching2.htm

Ijeomah, H. M., \& Aiyeloja, A. A. (2010). Ecotourism: An instrument for combating Renewable natural resources Degradation (pp. 441-470). In: Ijeomah, H. M., \& Aiyeloja (Eds.). Practical Issues in Forest and Wildife Resources Management. Green Canopy Consultants, Port Harcourt, Rivers State.

Kepe, T., Cousins, B., \& Turner, S. (2000). Resource Tenure and power relations in community context: The case of the Mkambati Area on the Wild Coast of South Africa. IIED, Discussion paper No. 16 London, p. 27.

Marguba, L. B. (2002). National parks and their benefits to local communities in Nigeria. Nigerian National Park Service, Abuja, p. 34

National Tiger Conservation Authority (Undated). Project Tiger Authority, Ministry of Environment and Forests, Government of India.

NEST. (1991). Threatened Environment: A National Profile. Nigerian Environmental Study/Action Team, Ibadan, p. 288.

Ogunjinmi, A. A. \& Ijeomah, H. M. (2010). Analysis of Ecotourism Activities in Kainji Lake National Park of 
Nigeria. Global Approaches to Extension Practice, 6(1), 86-94.

Serengeti National Park (2000). Park Management, Conservation and Research - Answers to conflict between man and Wildlife? Serengeti National Park. Retrieved from http://www.serengeti.org/main_serengeti.html 